\title{
Problems in Development of Electrical Power in Rural China
}

\author{
Peng Gao \\ Sales Department of NingXia Electric Power Corporation \\ Yinchuan 750001, Ningxia, China \\ MBA of North China Electric Power University \\ Beijing 102206, China \\ Guoliang Luo \\ Business Administration School, North China Electric Power University \\ Beijing 102206, China \\ Tel: 86-10-8079-4755Ｅ-mail: 1g11965@126.com
}

\begin{abstract}
With development of electric power in rural China for several decades, it has attained great achievements. However, under the circumstance when urban and rural development is balanced in China, problems in development of electric power in rural China seem more prominent, mainly characterized by disbalance of development structure, lagging of macro-management and policy, and lack of vitality in electric power corporations in rural China.
\end{abstract}

Keywords: Electric power in rural China, Development structure, Macro-management, Universal service, Microstructure

\section{Disequilibrium and lagging of development of rural electric power}

\subsection{Disequilibrium of industrial structure development of electric power}

Since the "Fifteenth National Congress", construction of power grid has increased with a speed of approximately $10 \%$ each year. In 2007, an investment of 245.1 billion Yuan was put into construction of power grid, increasing by $20.67 \%$. Resources of power grid become gradually optimized. By the end of 2007 , power assets accounted for $65 \%$ of electric power assets, whereas power grid assets accounted for only $35 \%$ of electric power assets. Obviously, scale of power grid is far behind that of power, and serious mismatching exists between scale of Chinese power grid and scale of power.

In 2007, investment of electric power in China was 549.3 billion Yuan, including an investment of 304.15 billion in power, which accounted for $55 \%$, and also an investment of 245.1 billion in power grid, which accounted for $45 \%$. The overall ratio of power grid investment to power investment in China is $4: 6$, which lags behind significantly the average ratio of 6:4 in developed countries. Influenced by the idea of "emphasis on construction of power plant, neglect of construction of supply network, and regardless of sales of electricity" in the past, construction of Chinese power grid has lagged behind construction of power for quite a long time. Although the country invested over 400 billion Yuan to reconstruct Chinese rural power grid and urban power grid in parts of cities on a large scale in the middle of 1990s, the situation of lagging in development of power grid hasn't been changed fundamentally. At present, China is in a development stage of developing rural areas through urban development and developing rural industry to subsidize agriculture, so lagging of rural electric infrastructure cannot satisfy requirements of establishing a new socialist countryside and realizing coordinated urban and rural development. Especially, district economic imbalance still exists. For example, the issue of social universal service in electric power hasn't been resolved in an appropriate way in western poverty-stricken areas.

The general situation of disparate development of industrial structure in electric power is as follows: power grid lags behind power, power distribution lags behind power transmission, rural power grid lags behind urban power grid and western power grid is the weakest. 


\subsection{Disparate development of regional structure}

Although rural electric power development has attained great achievements, generally speaking, level of rural electrification is still low, and obvious regional disparity exists between rural power utilization and rural power grid.

Considering rural power utilization in 2005, annual power consumption per capita in eastern rural areas was $970.9 \mathrm{kWh}$, which was 5.6 times as much as that in middle rural areas, and was 6.0 times as much as that in western rural areas.

From 1999 to 2005, average annual growth rate of power consumption per capita in eastern rural areas was $14.26 \%$, ranking the first; average annual growth rate of power consumption per capita in middle rural areas was $4.96 \%$, obviously lower than eastern rural areas; influenced by the policy of Western Development, average annual growth rate of power consumption per capita in western rural areas increased to $6.63 \%$, higher than western rural areas.

Comparing per capita household power consumption in rural areas, great differences exist between different provinces and municipalities. For example, rural per capita household power consumption in Beijing in 2006 was 434kWh, more than 14 times as much as that in Tibetan Autonomous Region.

\subsection{Lack of permanent mechanism in development of rural electric power}

Due to reasons of rural electric power system, investment mechanism and rural electric power development policy, foundation of Chinese rural power grid is still quite weak, unable to satisfy needs of rural economic and social development.

Since 1998, the country has launched rural power grid construction and reconstruction on a large scale. However, due to weak rural power grid foundation and too many historical defects, the overall reconstruction coverage of rural power grid is relatively small. At present, reconstruction coverage of power grid of $35-110 \mathrm{Kv}$ in the whole country is only $30 \%$, and reconstruction coverage of power grid below $10 \mathrm{Kv}$ is approximately $60 \%$. A large majority of power ancillary facilities for agricultural irrigation and drainage and User Tables of more than 15,000,000 rural households haven't been reconstructed, which affects agricultural production and rural residential life to a great extent.

Major grid frame structure of Chinese rural grid is still weak, and within the operation area of State Grid Corporation of China, power supply radius of $10 \mathrm{Kv}$ line in $25 \%$ of counties exceeds the standard distance, and power supply radius of low voltage line in $40 \%$ of counties exceeds the standard distance. According to statistics of 1706 county rural power enterprises, there are 343 countyregional single-supply power girds, accounting for $20.11 \%$; there are $2056110(66) \mathrm{kV}$ single-supply substations, accounting for $37.52 \%$; there are $531335 \mathrm{kV}$ single-supply substations, accounting for $42.5 \%$. The proportion of single-supply countyregional power grid and substations is high. Thus, once the line or power point connected with the major power grid is offstream, a large acreage of power will be cut.

Construction and reconstruction of rural power gird has resolved historical defects within a short period of time, and has satisfied demand of temporary rural economic development on rural power grid. However, in the long run, a stable and effective investment and financing mechanism in rural power gird hasn't been established, so the problem that rural power gird doesn't suit rural economic and social development in a new situation will recur. After reconstruction of rural power gird, there are mainly the following several issues in investment and financing:

Insufficient investment scale, which is mainly reflected in two aspects. On one hand, insufficient coverage of rural power gird construction. The proportion of rural towns covered in the first and second stage of rural power gird construction and reconstruction is $82.3 \%$, including $96.8 \%$ in the east, $87.7 \%$ in the middle, $68.2 \%$ in the west and $97.6 \%$ in the northeast. Residents from regions uncovered in reconstruction have strong complaints, and propose urgent demands. On the other hand, the issue of voltage class during construction of rural power grid. The focus of investment during the two stages of rural power grid construction is on voltage class of $10 \mathrm{kV}$ and below, while a little investment has been put into reconstruction of $35 \mathrm{kV}$ and $110 \mathrm{kV}$ power grid frames. Therefore, power point is relatively far in working of rural power grid, the $10 \mathrm{kV}$ line is too long, power distribution reliability and qualification rate of voltage is too low, and reduction of line loss is restricted, which all affect development of rural electric power and rural economy.

Weak capacity in investment and financing. All around the country, in addition to the "two cents" returned by the central finance, the space for electricity to increase price in all provinces and cities is quite limited. There is a big gap in repaying of investment in rural power grid reconstruction in the first and second stages, and the provincial power companies of "Governments Unify the Loan and Refund in Union" burden heavy pressure. Some provincial power companies don't have the ability to loan for construction and reconstruction of rural power gird, or just loan with a small amount, in the hope to relieve their pressure.

With completion of the second stage of rural power grid reconstruction, in the new situation of rapidly developed Chinese economy and establishment of a new socialist countryside, power consumption demand in many rural areas increases in a transnormal way, and the actual load has exceeded the stipulated value. The first and second stages of rural power grid reconstruction is based on a growth rate of 7\%-8\% in rural electric power, but actual growth rate of rural annual power consumption is up to $15 \%-16 \%$. In coastal developed regions, construction of rural power grid lags 
behind needs of rural economic development. In some countyregional power supply enterprises, due to mismatching between electricity sales amount and sales income and assets of large scale reconstruction, maintenance capital of rural grid facilities is utterly inadequate, which causes many rural areas unable to deliver and utilize power, and the phenomenon of bottlenecks in rural power grid is becoming increasingly prominent. Construction of rural power grid needs urgently strengthening, and financing gap for rural areas to continue to construct and reconstruct power grid is obvious.

At present, China is in the process of industrialization and urbanization, and space of growth in power consumption in rural areas is large. In 2007, countyregional annual household power consumption per capita was merely half of urban residents, equivalent to $1 / 21$ of per capita power consumption in America in 2004 and 1/5 of per capita power consumption in Japan. With construction of new socialist countryside and countyregional economic development, the secondary industry and the tertiary industry switch to rural areas, and the extensive rural residents' living standards are upturned, so rural power consumption increases rapidly. From 1998 to 2007, rural average annual growth rate of power consumption within the operation area of State Grid Corporation of China was $16.41 \%, 5$ percent faster than growth speed of the whole society, and the growth speed was up to $20-30 \%$ each year in part of areas. Most electrical supply equipment in the first and second stage of rural power grid reconstruction has been overloaded or fully loaded, calling for augmentation and expansion. It is predicted, State Grid Corporation of China during the $11^{\text {th }}$ "Five-Year" needed to invest 331.4 billion Yuan into rural power grid construction and reconstruction. However, the national financial investment cannot satisfy requirement of rural grid development, especially the great discrepancy between investment in construction of electric power in electroless areas stipulated and actual investment planned. For example, since 2006, the total investment in construction of rural power grid in electroless areas within the operation area of State Grid Corporation of China only accounted for about $24 \%$ of the total amount of project investment demand. Furthermore, the financial support of the country was mainly for construction of electric power in Midwestern electroless areas.

\section{Serious vacancy in macro-management of rural electric power}

\subsection{Lack of a unified authoritative organization, and serious vacancy of management function in rural electric power}

In terms of the central government, after the repeal of State Economic and Trade Commission, it hasn't been confirmed which department should carry on management function of rural electric power. In terms of local government, on one hand, corresponding with the central government, local government weakens the industrial function of rural electric power after reform in government organization; on the other hand, in the process of demarcation of rural electricity enterprises to top departments, joint-stock restructing and establishment of the relation of escrow wholesale, some local governments also withdraw from the industrial function of rural electric power with weakening on the management function of rural electrical companies. In terms of rural electric power plan and facility maintenance, due to lack of authoritative coordination and organization departments, serious vacancy exists in the management function, such as, responsibility of universal service in rural electric power, supportive policy of rural electric power development (including direct investment in rural electric power, offer of soft loan or low-interest loan, and subsidies granted for policy considerations) and offer of preferential policies of fiscalit and price, etc.

Due to indefinite of segregation of duties in macro-management and industrial organization management, reform of property rights system in rural electric power is tremendously restricted.

\subsection{Indefinite segregation of duties and responsibilities of central and local functions}

Segregation of duties and responsibilities in management of rural electric power by the central and local government has great effect on transmission and distribution system and on development of rural electric power. Under the policy of electrovalency with similar grid and similar valency, reform of transmission and distribution system is influenced by local finance and investment and financing of local government. Since the local government gives priority to influences of reform of rural electric power system upon local fiscalit, its management level and ideology plays a restrictive role in reform of rural electric power. Under the actual constraint of financial target, there exists great uncertainty for local government to support sustainable development of rural electric power and to perform the public service of electric power.

During operation of the existing system, due to disagreement between interests of central and local government and due to conflict of the policy target, segregation of duties and responsibilities of management of rural electric power between the central and local government directly influences the next step of reform in rural electric power system.

\subsection{Acute contradiction between local rural power enterprises and enterprises directly under the central ministries}

Currently, Chinese electrical industry is in an important historical period of system transformation, mechanism conversion, structure adjustment and alteration of growth mode. In the process of reform in electric power system, rural electric power belongs to power distribution, and is an important power purchase entity in Chinese power market in the long run, so a fair market development environment should be built. However, due to non separation of transmission and distribution, imperfectness of the planning system of power grid, non separation of main and secondary power grid 
enterprises, and inadequate supervision on electric power, and out of consideration of local enterprise interests, central and local state-owned rural grid enterprises usually cannot implement a unified plan and rational redistribution of power gird according to technical and developmental features of power grid per se. Dependence on advantages of systems, such as planning, design, synchronization and dispatching in various degrees, efficient and orderly development of local rural (distribution) power enterprises is influenced. At the same time, since urban and rural power supply is assumed by two different enterprises, and great discrepancy exists in the scale of enterprises, so it is difficult to realize urban and rural equilibrium by means of adjusting electrovalency and to realize similar grid and valency of electric power in urban and rural areas.

\section{Insufficient vitality of microstructure of rural electric power}

\subsection{Asset dispute in rural electric power affects enthusiasm in investment into rural electric power.}

Debt funds for the first and second stages of rural power grid reconstruction taken charge of by State Grid Corporation of China and China Southern Power Grid Corporation was mainly burdened by provincial power grid companies. According to documents at that time, $20 \%$ of national debt assets in direct supplied and direct controlled counties were contributed by the State Power Corporation, owned by the central government. 20\% of national debt assets in wholesale counties were contributed by provincial planning commission, owned by local government. Afterwards, the country issued the policy of two cents for repaying of electric price, and repaying of rural grid reconstruction was actually assumed by the whole society. So far, dispute still exists between the central power grid enterprise and local government and local power enterprises about property ownership of reconstruction assets in rural power grid. This, to great extent, affects enthusiasm of all parties in investment and operation in rural power grid.

In the process of operation of power supply enterprises, disputes exist about ownership of assets, use rights and earning rights of assets. In addition, right, obligation and interest are not in agreement, so it is difficult to bring advantages of the system into full play in actual operation.

\subsection{Distempered stimulation and constraint mechanism causes insufficient ability of rural power enterprises to make further advances.}

In the following, we are going to analyze respectively the four types of power supply enterprises.

Escrow rural power enterprise. Escrow refers to industrial escrow entrusted by local County (City, District) People's Government to provincial (autonomous region, directly administered municipal people's government) power companies for its subsidiary county power supply enterprises. The main purpose is to strengthen management, to carry out separation of government function from enterprise management, to take control over employee expansion, to reduce management cost and to standardize the market of power supply. Therefore, escrow is a sort of industrial management mode with administrative flavor, and it is not an actual enterprises behavior, with features of timeliness and temporary transitivity.

Since escrow counties don't have assets tie relationship with provincial companies, the latter has no means to carry out an overall planning and investment construction for rural power grid of escrow counties. Their investment in economically underdeveloped areas is not enough, unable to realize sustainable development of rural power grid and rural electrification.

Joint stock enterprises. Provincial power grid enterprises and local government together contribute to establish joint-stock county power supply enterprises, which corresponds with requirements of socialism market economy system and is helpful for establishment of modern enterprise system. In actual operation, running of joint-stock enterprises is not standard. For instance, although some county power supply enterprises belong to joint-stock enterprises, they don't function according to standards of joint-stock companies, and have defects in percentage of shares and in governance structure, etc. Acute contradictions exist among stakeholders in terms of investment in rural power grid, compartmentalization of power supply operation area and power grid planning, etc.

Direct supplied and direct controlled enterprises. Both State Grid Corporation of China and China Southern Power Grid Corporation set up rural electricity department responsible for rural electric power. Under the circumstance when there is vacancy in macro-management functions in rural electric power, most functions of rural electric power management are assumed by State Grid Corporation of China and China Southern Power Grid Corporation. Specific affairs are put under centralized management by rural electricity administration departments, and organizational management is conducted from rural Electricity Department of State Grid Corporation of China (China Southern Power Grid Corporation) to rural power users. Power grid enterprises are involved in the status quo of multiple levels, heavy tasks and limited management personnel, so they are faced up with double pressure and risks of macro-management and operation management.

Self supplied and self controlled enterprises. Currently, in addition to local hydroelectric power system, self supplied and self controlled enterprises also include county power supply enterprises in Tibetan Autonomous Region, Xinjiang 
Production and Construction Army Corps, oil field, forest and agricultural reclamation. Constitution of areas and units is complicated, so their management levels and operation conditions are all different. Most of their assets belong to local government, and they are independent operation entities, so contradictions and interest conflicts are inevitable between these enterprises and local provincial power grid companies in terms of on-grid price, power supply area and assets, etc.

Self supplied and self controlled enterprises are mainly concentrated on Midwestern areas. Affected by underdeveloped local economy and lack of investment capacity of local government, a great majority of enterprises are insufficient in funds for development, so they are generally lagging behind in ability to develop and to make further progress. With development of rural economy, some problems come to light, such as weak reliable power supply capacity, low management level, low capacity of risk resistance, which cannot be resolved in isolation. In the situation of building a well-off society in an all-round way, balancing urban and rural development, and establishment modernized agriculture, the mode of self supply and self control is faced up with challenges of reform and development.

\section{Vacancy in the policy of universal service in rural electric power}

Rural electric power has the double characteristics of public welfare and operation. At present, provincial power companies are the major obligation and implementation entities of universal service in Chinese electric power. In the existing system of electrovalency, electrovalency between different areas, different business and different voltage classes is realized by cross-subsidization. On one hand, restricted by performance assessment criteria of State-Owned Assets Supervision and Administration Commission, operational benefit and developmental ability of power grid companies affect income of all levels of management personnel. On the other hand, due to huge investment in power grid, within rural marginal power operation areas, the ability of grid distribution development and universal service in electric power is faced up with great difficulties, universal service of rural electric power is lacking in an effective mechanism, and there is contradiction between public welfare burden and operation target of rural power enterprises.

The major problems in universal service of Chinese rural electric power are generalized as follows: indefinite entity, lack of definite goal, scope \& legal and policy foundation, lack of definite fund sources and cost compensation mechanism, and large fund gap required for implementation of universal service in electric power.

\section{References}

China Electricity Council. (2008). China Electric Power since the 30 years of Reform and Opening-up. CEPP.

Luo, Guoliang. (2009). Institutional Reform in Rural Power: New Environment, New Issues and New Content. Energy, No. 7. 